\title{
Effect of Irrigation on Maize Yield (Zea mays L.)
}

\author{
János Nagy \\ University of Debrecen, Centre for Agricultural Sciences, \\ Faculty of Agricultural Sciences, \\ Department of Land Use and Rural Development, Debrecen
}

\section{SUMMARY}

We have been continually examining the fertilizer and irrigation reaction of commonly cultivated maize hybrids for nearly twenty years at the Látókép experimental station of the Center for Agricultural Sciences, Debrecen University.

Upon evaluating the results, it can be established that year significantly influences the size of yield. Between the years of 1999 and 2002, in the average of applied fertilizers the difference is 3,4 t/ha, but even in irrigated treatments it reaches $3 \mathrm{t} / \mathrm{ha}$. This is more than the effect of irrigation. Of the applied agrotechnical elements, the yield increasing effect of fertilization is the greatest and can even be greater than the effect of year. The yield increasing effect of fertilization can be reliably detected with small and medium doses, but at higher doses a plateau section is reached, where it is not worth applying more nutrients. Cultivation with irrigation can only be done with appropriate nutrient supply, due to the positive correlation of the two factors. The positive correlation also means that if the water supply of the plant declines, less fertilizer is needed for safe production. The two factors (irrigation and fertilization) have to be increased or decreased at the same time.

According to the experiment, in unirrigated treatments, 90 $\mathrm{kg} / \mathrm{ha}$ nitrogen and the related phosphorus and potassium are enough, while in irrigated treatments this was $120 \mathrm{~kg}$.

\section{INTRODUCTION}

The size of a plant culture's yield is a result of interactions between genetic, ecological and technological factors. In scientific research, it is necessary to evaluate certain factors - in this case, plant cultivation factors - separately and jointly as well.

The basis for our research comes from the results of multifactorial long-term experiments (sowing $\mathrm{x}$ soil cultivation $\mathrm{x}$ fertilization $\mathrm{x}$ irrigation $\mathrm{x}$ plant density $\mathrm{x}$ genotype) of the Center for Agricultural Sciences, Debrecen University, that are unique and acknowledged in Europe. The research program builds on the results of research work with similar thematics carried out by Györffy and Berzsenyi at Martonvásár, which covers many decades and provides a reliable scientific background.

The method and extent of fertilization should be determined not on the basis of maximum yield, but solely on the basis of profitability (Irvine, 1963). According to Debreczeni (1980) the upper limit of fertilizer application has to be determined on the basis of optimal level of economic cultivation originating from surplus yield. Both Hungarian and foreign scientific publications agree that from the factors influencing fertilizer effect, weather, soil characteristics, water supply, uniformity of plant stock, cultivated plant and the nutrient reaction of the

strain are the most decisive. Weather, since it regulates heat and moisture supply of the cultivation site, has an effect on material transformation in the soil, as well as on the growth and nutrient uptake of plants and, thus, on the efficiency of fertilizers (Kramer, 1963; Kovács, 1982; Drimba and Ertsey, 2003; Drimba et al., 2000; Ertsey and Drimba, 1995; Nagy, 1996). According to the majority of experiments, the fertilizer effect is medium or good in a moderately dry year. In case of drought, plants develop well during the first half of development, in the second half due to the increased LAI as well as the increased need for water, maize will get into a severe water deficiency, which results in a significant yield decrease (Debreczeni and Debreczeniné, 1983; Nagy, 1997). The amount of precipitation, or the moisture stored in the soil, modifies the need and effect of fertilizers. Fertilizer effect increases when activities leading to optimal water supply and decreases when reaching harmful levels of excess water (Nagy, 1994). The influencing effect of soil characteristics depends primarily on soil fertility, thickness of the productive layer and on water balance (Sarkadi, 1975; Györffy, 1976). Optimal Nsupply significantly contributes to grain number per cob, and to a smaller extent to the increase of the thousand grain weight (Bocz and Nagy, 1981). In case of N-deficiency, dry matter accumulation is smaller in maize plants and the dynamics of dry matter accumulation is slower (Hanway and Russel, 1969; Berzsenyi, 1993). Fertilization is decisive both in macro and micro element uptake (Németh and Buzás, 1991). With appropriate N-supply, a fast increase of leaf area in the early phase of development can be promoted, and thus the optimal LAI value can be sustained longer, which means an advantage from the aspect of assimilate flow to the grain yield as well as a favourable harvest index value (Dobos and Nagy, 1998; Berzsenyi, 1993). This advantage, however, does not ensure an economic profit, since maize goes through water deficiency earlier, which peaks in the reproductive phase and thus results in a yield decrease.

We can ensure constant water supply and undisturbed physiological operation of plants with irrigation. In areas that are poor in precipitation, irrigation guarantees yield. Results of experiments prove that irrigation in general, especially in cases of drought, highly increase the yield of maize. Irrigation will be more essential in specific parts of the country for safe and intensive production of maize (Szőke Molnár, 1977). It is crucial for farmers to irrigate maize on greater areas to avoid yield fluctuations due to the effect of years. Especially the extremely 
droughty weather lasting from the second half of the 1980 's until the mid 1990's put irrigation in the center of attention. Accurate precipitation forecasts can only be given with the knowledge of precipitation and groundwater conditions regarding a specific plot (Balogh, 1978). If precipitation and the easily accessible water supply of the soil do not satisfy the needs of the plant, then the deficiency has to be compensated with irrigation (Petrasovits, 1988).

Water supply plays a significant role in the utilization of fertilizer active substances especially that of nitrogen. Due to the changing precipitation, the effect of fertilization strongly varies on an annual basis. The correlation of irrigation and fertilization has been investigated by many Hungarian researchers. The irrigation and fertilizer research results of Nagy $(1995,1997,1999)$ have indicated that irrigation improves the efficiency of fertilization and there is a strong correlation between fertilizer utilization and the water supply of a plant. In irrigated treatments - which means a higher yield level - economic fertilizer doses are greater, due to the positive correlation of irrigation $\mathrm{x}$ fertilization, than in unirrigated treatments. In irrigated treatments, the effect of year is moderate and yield fluctuation decreases. The annual fertilizer reaction differs to a smaller extent than in unirrigated treatments, thus nutrient supply can be planned with greater safety. The irrigation and fertilization experiment results of Hank and Frank (1951) have proved that irrigation increases the efficiency of fertilization. The efficiency of fertilizers also depends on agroecological conditions (Láng, 1981).

\section{MATERIALS AND METHODS}

We have been continually examining the fertilizer and irrigation reactions of commonly cultivated maize hybrids for nearly twenty years at the Látókép experimental station of the Center for Agricultural Sciences, Debrecen University.

Soil characteristics. The soil of the Experimental Station is lowland chernozem with lime deposits formed on loess. The N- and P-supply of the soil is medium, its $\mathrm{K}$-content is high (humus content $=2,8$ $3,0 \%$, Total. $\mathrm{N}=0,14-0,18 \% ; \mathrm{AL}-\mathrm{P}_{2} \mathrm{O}_{5}=130-200$ $\mathrm{mg} / \mathrm{kg}, \mathrm{AL}-\mathrm{K}_{2} \mathrm{O}=240-280 \mathrm{mg} / \mathrm{kg}$ ). The thickness of the humus layer is $70-90 \mathrm{~cm}$. The $\mathrm{pH}(\mathrm{KCl})$ valueis 6,2 ; the saturation percentage is 43 . Microelement deficiency could not be detected. The groundwater level is between $6-8 \mathrm{~m}$. The VKmin value of the soil is $27-29 \mathrm{tf} \%$. The $0-100 \mathrm{~cm}$ soil layer can store 275 $\mathrm{mm}$, while the $100-200 \mathrm{~cm}$ layer can store $265 \mathrm{~mm}$ moisture. The useful VK at $0-100 \mathrm{~cm}$ is $157 \mathrm{~mm}$, at $100-200 \mathrm{~cm}$ it is $150 \mathrm{~mm}$.

Fertilizer treatments: In the $1 \mathrm{~N}: 0,75 \quad \mathrm{P}_{2} \mathrm{O}_{5}: 0,88$ $\mathrm{K}_{2} \mathrm{O}$ constant ratio NPK dosage experiment the basic dose is $80 \mathrm{~kg} / \mathrm{ha}$ - from which $\mathrm{N}$ is $30 \mathrm{~kg} / \mathrm{ha}-$ and we have applied 1, 2, 3, 4, 5-times this dosage, along with an unfertilized control. The identical NPK ratio doses were simply marked with the quantity of $\mathrm{N}$, during the evaluation.

We applied irrigation in an amount that is close to the calculated need of the plant $(273 \mathrm{~mm})$ : irrigation was done with a NADIR type, $75 \mathrm{~cm}$ division trickle irrigation system.

The experiment was done in four repetitions. In a row setup, 6 fertilizer treatments were setup in random order within one repetition, in irrigated and unirrigated treatments with identical 70 thousand plant density. The size of one repetition is: $1260 \mathrm{~m}^{2}$, the fertilized plots $210 \mathrm{~m}^{2}$.

Weather characteristics. We have used the data between 1961-1990 to characterize the climate of Debrecen (30 year average). (Source: National Meteorological Service, Tables 1-2.)

30 year average of Debrecen's air temperature $\left({ }^{\circ} \mathrm{C}\right)$

\begin{tabular}{|c|c|c|c|c|c|c|c|c|c|c|c|c|}
\hline Month & I. & II. & III. & IV. & V. & VI. & VII. & VIII. & IX. & $\mathrm{X}$. & XI. & XII. \\
\hline Mean & $-2,6$ & 0,2 & 5,1 & 10,7 & 15,8 & 18,7 & 20,3 & 19,6 & 15,8 & 10,3 & 4,5 & $-0,2$ \\
\hline maximum & 0,6 & 4,1 & 10,4 & 16,6 & 21,7 & 24,6 & 26,5 & 26,1 & 22,4 & 16,5 & 8,5 & 2,6 \\
\hline minimum & $-5,5$ & $-3,0$ & 0,6 & 5,4 & 10,1 & 13,1 & 14,4 & 13,7 & 10,3 & 5,3 & 1,3 & $-2,8$ \\
\hline \multicolumn{7}{|c|}{ Average temp. of winter season (X-III.) } & & & & & & 2.9 \\
\hline \multicolumn{7}{|c|}{ Average temp. of growing season (IV-IX.) } & & & & & & 16.8 \\
\hline \multicolumn{7}{|c|}{ Annual mean temp. } & & & & & & 9.85 \\
\hline
\end{tabular}

30 year average of precipitation $(\mathrm{mm})$ in Debrecen

\begin{tabular}{|c|c|c|c|c|c|c|c|c|c|c|c|c|}
\hline Month & I. & II. & III. & IV. & V. & VI. & VII. & VIII. & IX. & $\mathrm{X}$. & XI. & XII. \\
\hline Precipitation & 37 & 30 & 34 & 42 & 59 & 80 & 65 & 61 & 38 & 31 & 45 & 44 \\
\hline \multicolumn{7}{|c|}{ Total precip. of the winter season(X-III.) } & & & & & & 221 \\
\hline \multicolumn{7}{|c|}{ Total precip. of the growing season (IV-IX.) } & & & & & & 345 \\
\hline \multicolumn{7}{|c|}{ Total annual precip. } & & & & & & 566 \\
\hline
\end{tabular}


Upon evaluating the precipitation of the examined period, it was established that in the year of 2002, during the winter season (X-III.), less precipitation fell than the average of 30 years. In the other years, there was average amount of precipitation. The precipitation that fell during the growing season shows great fluctuation. In 2000, very little, while in 2001, an amount that exceeded the average fell (Figure 1).

Figure 1: Total precipitation of the examined period, $\mathbf{m m}$ (Debrecen, 1999-2002)

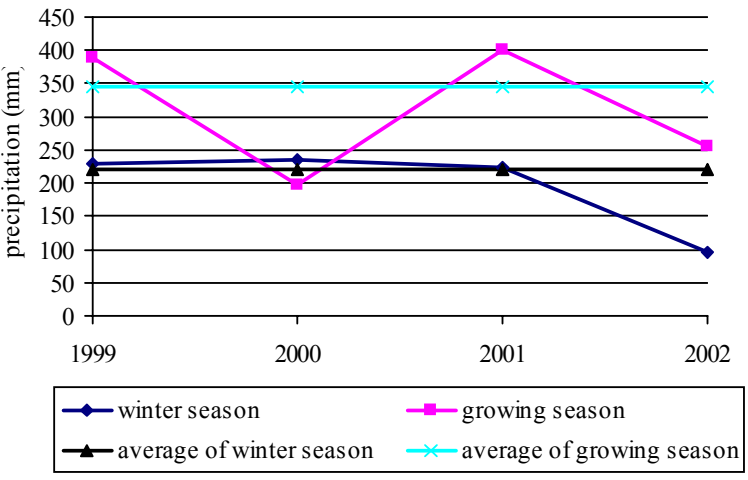

The temperature of the growing season, except for 2002, exceeded the 30 year average in all years. The temperature of the winter season fluctuated around the average. It was significantly warmer in 2001. The low value of the 2002 winter season can be due to the record cold of December 2001 (Figure 2).

Figure 2: Temperature of the examined period (Debrecen, 1999-2002)

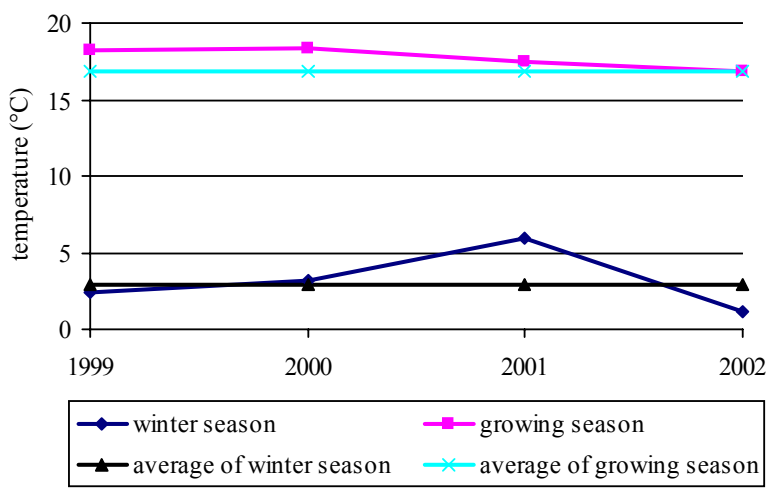

\section{METHOD OF EVALUATION}

The statistical evaluation was done with an IBM compatible personal computer, using SPSS 9.0 for Windows statistical program package. The computer program includes the most modern statistical methods about the operation of the database, from descriptive statistics to the most complicated multivariable mathematic statistical methods. A great advantage of the program package is that we can use not only prepared statistical tests but we can also prepare simple models and we can do their statistical evaluations. An advantage of this is that many built in statistical tests require very strict application conditions, which are not realized in the soil-plantatmosphere system, but the methods fitted to the characteristics of the examined phenomenon can provide more reliable results. Variance analysis is often used for the evaluation of experimental data in agricultural research. Presently, many techniques of variance analysis exist, which make it possible to choose the most appropriate evaluation method by considering the distinctiveness of the task. The reliability of the evaluation depends on the method of determining the error, which is really the function of squared deviance (SQ) calculation technique. The statistical program package makes it possible to reliably evaluate the linear model according to the true setup of the experiment.

We chose a General Linear Model, which is the generalised form of the variance analysis, to compare the mean values of the treatment effects. This method is a combination of linear regression analysis and variance analysis. In this model, yield $(\mathrm{t} / \mathrm{ha})$ is the dependent variant while irrigation and fertilization is the fix factor. The effects of treatments on the yield are symmetrically around the main average of the experiment. Since the main average of the experiment differs from zero, we have built in a constant parameter into the model. Since the experiment is multifactorial, balanced and there are no missing plot data, we chose the third type (Type IIV.) from the four options built into the statistical program package when calculating squared sums of deviances. The square sum deviances were identical with ones that were calculated with the Yates method. The Yates method essentially uses the weighted square deviance technique of the averages when calculating square sums. This method is widely known in agricultural research, since Sváb describes this technique when introducing variance analysis in his book.

\section{RESULTS}

We examined the effect of fertilization on the yield of maize by using the yield data of four years, at six fertilizer levels in four repetitions, in irrigated and unirrigated treatments at the experiment set up at the experimental station of Látókép. Data obtained during the experiment was evaluated with variance analysis. According to the examinations, irrigation and fertilization are strong factors in influencing yield, the main effect of irrigation and fertilization are strongly significant (Table 3). The irrigation $\mathrm{x}$ fertilization correlation is significant, which indicates that the yield increasing effect of fertilization does not differ in irrigated or unirrigated treatments. Since the main effect and correlation of fertilization are significant, it can be established that in the years of examinations fertilization reliably and significantly increased yield in all years. 
Result of analysis of variance

(Debrecen, 1999-2002)

Dependent Variable: $\mathrm{t} / \mathrm{ha}$
\begin{tabular}{|l|r|r|r|r|r|}
\hline \multicolumn{1}{|c|}{ Source } & $\begin{array}{c}\text { Type III Sum of } \\
\text { Squares }\end{array}$ & df & \multicolumn{1}{c|}{ Mean Square } & \multicolumn{1}{c|}{ F } & Sig. \\
\hline Corrected Model & $15921.086^{\mathrm{a}}$ & 11 & 1447.371 & 373.847 & .000 \\
\hline Intercept & 483215.067 & 1 & 483215.067 & 124811.419 & .000 \\
\hline Irrigation & 2282.149 & 1 & 2282.149 & 589.465 & .000 \\
\hline Fertilization & 13540.094 & 5 & 2708.019 & 699.464 & .000 \\
\hline Irrigation x Fertilization & 98.843 & 5 & 19.769 & 5.106 & .000 \\
\hline Error & 20581.220 & 5316 & 3.872 & & \\
\hline Total & 519717.373 & 5328 & & & \\
\hline Corrected Total & 36502.307 & 5327 & & & \\
\hline
\end{tabular}

${ }^{\mathrm{a}} \mathrm{R}$ Squared $=.436$ (Adjusted R Squared $=.435$ )

The comparison of estimated values by the linear model and the values measured in the experiment are interesting; as the r-square value indicates, this shows a strong correlation among yield, fertilization and irrigation. It has to be emphasized that the medium strong correlation is statistically reliable. The explanation for this is that variance analysis, or General Linear Models, used in the up-to-date statistical computer programs build up the amount of yield from linear combinations of treatment effects. In our experiments, we have had six fertilizer doses and, as it is commonly known, fertilizer does not influence yield in a linear way. Thus, disregrading the squared effect weakens the value of linear correlation.

The yield increasing effect of fertilization is not more than $4 \mathrm{t} / \mathrm{ha}$ in irrigated treatments, in the average of the examined period. In irrigated treatments, this value is close to $5 \mathrm{t} /$ ha (Table 4). Irrigation also improves the natural nutrient utilization of maize, since irrigation increased yield by $1 \mathrm{t} /$ ha on average in unfertilized treatments. With greater fertilizer doses, the yield increasing effect of irrigation is also greater, which can be explained with the positive correlation between nutrient and water supply. In the case of $120 \mathrm{~kg} \mathrm{~N} / \mathrm{ha}$, irrigation increased the yield of maize by $1,7 \mathrm{t} / \mathrm{h}$ a on average.

When evaluating the specific years separately, the above mentioned tendency can be established, in years with better water supply, the utilization of fertilizer is better and has greater yield increasing effect. In irrigated treatments, it is rare that greater fertilizer doses cause yield depression.

Effect of fertilization and irrigation on yield of maize

Table 4 (Debrecen, 1999-2002)

\begin{tabular}{|c|c|c|c|c|c|c|}
\hline \multirow{2}{*}{\multicolumn{2}{|c|}{ Fertilization, kg/ha }} & \multicolumn{5}{|c|}{ Years } \\
\hline & & \multirow{2}{*}{$\begin{array}{l}1999 \\
7.10406 \\
\end{array}$} & \multirow{2}{*}{$\begin{array}{l}2000 \\
4.75853 \\
\end{array}$} & \multirow{2}{*}{$\begin{array}{l}2001 \\
6.17360 \\
\end{array}$} & \multirow{2}{*}{$\begin{array}{l}2002 \\
5.39191 \\
\end{array}$} & \multirow{2}{*}{$\begin{array}{r}\text { Average } \\
5.84579 \\
\end{array}$} \\
\hline \multirow{7}{*}{ Non irrigation } & Non fertilization & & & & & \\
\hline & $\mathrm{N} 30, \mathrm{P} 23, \mathrm{~K} 27$ & 9.65721 & 7.04755 & 9.07853 & 6.99381 & 8.18110 \\
\hline & N60, P45, K53 & 10.78821 & 8.46341 & 10.11313 & 8.06734 & 9.34514 \\
\hline & N90, P68, K80 & 11.70811 & 8.81026 & 10.61030 & 8.48229 & 9.88648 \\
\hline & N120, P90, K106 & 12.55059 & 9.39638 & 10.65479 & 8.15027 & 10.16672 \\
\hline & N150, P113, K133 & 12.69718 & 9.08568 & 10.10295 & 7.36949 & 9.78785 \\
\hline & Average & 10.75089 & 7.92697 & 9.45555 & 7.40918 & 8.86884 \\
\hline \multirow{7}{*}{ Irrigation } & Non fertilization & 8.15734 & 5.82608 & 6.76232 & 6.79000 & 6.87246 \\
\hline & $\mathrm{N} 30, \mathrm{P} 23, \mathrm{~K} 27$ & 10.99097 & 7.60855 & 9.76174 & 8.69374 & 9.24819 \\
\hline & N60, P45, K53 & 12.29525 & 9.24585 & 10.71096 & 9.52752 & 10.42822 \\
\hline & N90, P68, K80 & 13.12638 & 9.79866 & 11.28975 & 10.78315 & 11.23258 \\
\hline & N120, P90, K106 & 13.73399 & 10.54522 & 11.44413 & 11.60194 & 11.81418 \\
\hline & N150, P113, K133 & 13.55553 & 10.14902 & 10.56689 & 11.68730 & 11.47107 \\
\hline & Average & 11.97658 & 8.86223 & 10.08930 & 9.84727 & 10.17778 \\
\hline \multirow{3}{*}{ LSD5\% } & & \multicolumn{2}{|l|}{ Irrigation } & & \multicolumn{2}{|r|}{0,106} \\
\hline & & \multicolumn{2}{|l|}{ Fertilization } & & \multicolumn{2}{|r|}{0,183} \\
\hline & & \multicolumn{2}{|c|}{ Irrigation $\mathrm{x}$ Fertilization } & & \multicolumn{2}{|r|}{0,259} \\
\hline
\end{tabular}


The Figure 3 shows the average yields of the 1999-2002 period. In unirrigated treatments, $90 \mathrm{~kg}$ $\mathrm{N} /$ ha fertilizer dose is enough to achieve yields that are close to maximum, while in irrigated treatments this can even be $120 \mathrm{~kg} \mathrm{~N} / \mathrm{ha}$.

\section{ACKNOWLEDGEMENT}

This research was supported by the Hungarian National Research Fund (OTKA T031989).

\section{Figure 3: Effect of fertilization on maize yield under irrigated an non-irrigated conditions}

(Debrecen, 1999-2002)

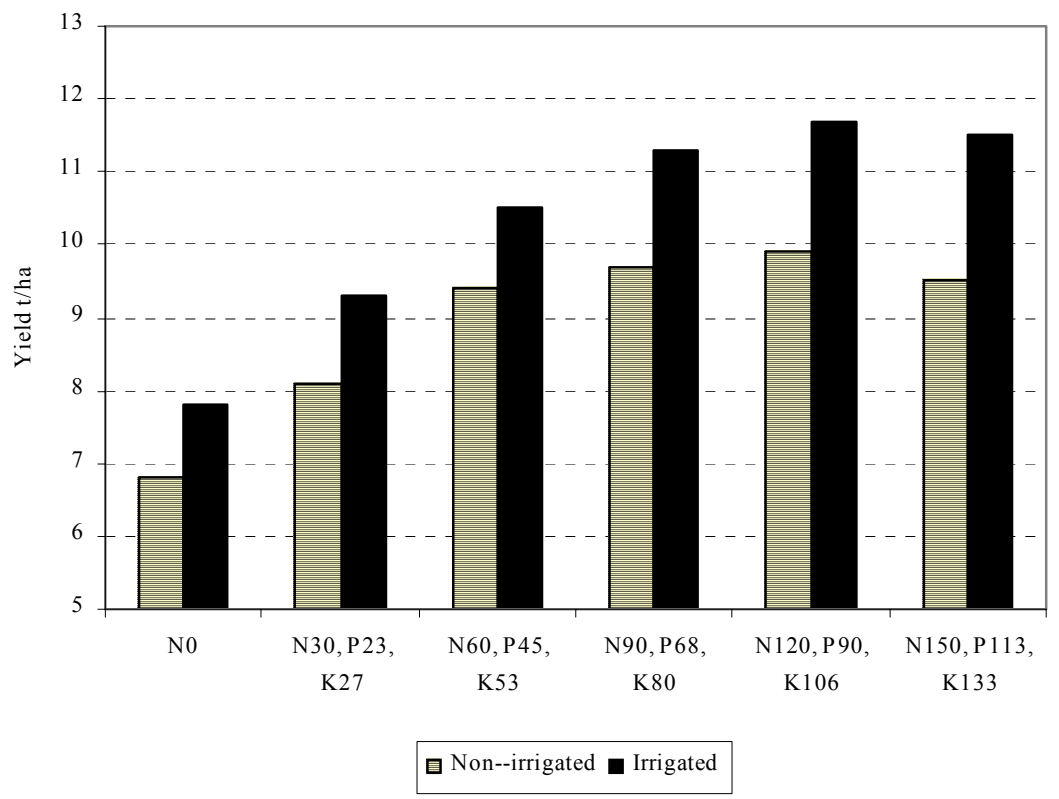

\section{REFERENCES}

Balogh, J. (1978): Calculating water needs in irrigation farming. Mezőgazdasági Kiadó, Budapest

Berzsenyi, Z. (1993): The effect of N-fertilization and year on the grain yield of maize hybrids (Zea mays L.) and $\mathrm{N}$-fertilizer reaction in long-term experiments, in the years of 1970-1991. Növénytermelés, 42. 1. 49-63.

Bocz, E.-Nagy, J. (1981): Optimizing water and nutrient supply of maize and its effect on the weight of yield. Növénytermelés, 30. 6. 539-549.

Box, G. E. P.-Wilson, K. B. (1951): In the Experimental Attainment of Optimum Conditions. Journal of the Royal Statistical Society, 13. 1.

Debreczeni, B. (1980): Artifical fertilization. Acta Agronomica, 29. 117-225.

Debreczeni, B.-Debreczeni, B-né (1983): Correlation of nutrient water supply. Mezőgazdasági Kiadó, Budapest

Dobos, A.-Nagy, J. (1998): The effect of year and fertilization on the dry-matter production of maize (Zea mays L.). Növénytermelés, 47. 5. 513-524.

Drimba, P.-Ertsey, I. (2003): Evaluation of maize yield in the function of fertilization with regards to risks. Kukorica hibridek adaptációs képességének és termésbiztonságának javítása. Debrecen, 149-163.

Drimba, P.-Ertsey, I.-Petró, Zs. (2000): Risk Programming Models for Planning Plant Production. $17^{\text {th }}$ European Conference on Operational Research, Budapest, 120.
Ertsey, I.-Drimba, P. (1995): A few characteristics of decision support models applicable in agriculture. DATE, Tud. Közl., Debrecen, 53-68.

Győrffy, B. (1976): Evaluating plant cultivation factors on the yield of maize. Agrártudományi Közl., 35. 239-266.

Hank, O.-Frank, M. (1951): Correlation between soil nutrient supply and water consumption in specific plants. ÖKI Évkönyv, Szarvas

Hanway, J. .J.-Russel, W. A. (1969): Dry-matter accumulations in corn (Zea mays L.) plants: Comparisons among single-cross hybrids. Agron. J., 61. 947-951.

Huzsvai, L.-Nagy, J. (1995): Optimizing experiments in planning of tillage and plant cultivation research. Növénytermelés, 44 . 5-6. 483-491.

Irvine, F. R. (1963): Soils and crops. Oxford University Press, London

John, P. W. M. (1971): Statistical Design and Analysis of Experiments. New York, McGraw-Hill

Kovács, G. J. (1982): Critical ecophysical relationship of waterand nutrient dynamics of maize. Növénytermelés, 31. 4. 355365.

Kramer, P. I. (1963): Water stress and plant growth. Agron. J. Madison, 55. 31-35.

Láng, I. (1981): Report on the national survey results of agroecological potential. Agrártudományi Közl., Budapest, 40. 29-98. 
Nagy, J. (1994): The effect of fertilization and irrigation on the yield of maize (Zea mays L.) hybrids with varions genotypes. Unipress, Padova, 421-440.

Nagy, J. (1995): Evaluating the effect of fertilization on the yield of maize (Zea mays L.) in different years. Növénytermelés, 44. 5-6. 493-506.

Nagy, J. (1996): Evaluating the effect soil cultivation and fertilization on the yield of maize (Zea mays L.). Agrokémia és Talajtan, 45. 1-2. 113-124.

Nagy, J. (1997): The effect of fertilization on the yield of maize (Zea mays L.) in unirrigated and irrigated cultivation. Agrokémia és Talajtan, 46. 1-4. 275-288.

Nagy, J. (1999): Evaluation of interaction between irrigation and soil cultivation in maize production. Acta Agronomica, 47. 2. 181-190.
Németh, T.-Buzás, I. (1991): Long-term nitrogen fertilization experiement on Nitrogéntrágyázási tartamkísérlet humuszos homok- és mészlepedékes csernozjom talajon. Agrokémia és Talajtan, 40. 399-408.

Petrasovits, I. (1988): Main questions of agrohidrology. Akadémiai Kiadó, Budapest

Sarkadi, J. (1975): A műtrágyaigény becslésének módszerei. Mezőgazdasági Kiadó, Budapest

Sváb, J. (1981): Biometrical methods in research. Mezőgazdasági Kiadó, Budapest

Szőke Molnár, L. (1977): Economical questions of irrigated maize production. Akadémiai Kiadó, Budapest

Winer, B. J. (1971): Statistical Principles in Experimental Design. New York, McGraw-Hill 